\title{
Comparison of the Lifecycle Cost Structure of Electric and Diesel Buses
}

\author{
Marek Potkány \\ Technical University in Zvolen \\ Faculty of Wood Sciences and Technology \\ Department of Business Economics \\ Slovak Republic \\ e-mail: potkany@tuzvo.sk \\ Jiř́ Hanzl \\ Institute of Technology and Business in \\ České Budějovice \\ Faculty of Technology \\ Czech Republic \\ e-mail: hanzl@mail.vstecb.cz
}

\author{
| Martina Hlatká \\ Institute of Technology and Business in \\ České Budějovice \\ Faculty of Technology \\ Czech Republic \\ e-mail: hlatka@mail.vstecb.cz \\ Marek Debnár \\ Technical University in Zvolen \\ Faculty of Wood Sciences and Technology \\ Department of Business Economics Slovak \\ Republic \\ e-mail:xdebnarm2@is.tuzvo.sk
}

DOI 10.17818/NM/2018/4SI.20

UDK 656.12

629.341

Preliminary communication

Paper accepted: 28. 8. 2018

Summary

The pressure to the environment protection within the concept of sustainable development and many national initiatives is constantly rising. This is also reflected in the field of transport. Currently, the issue of electro mobility is often discussed. Acquisition of eco-friendly cars or electric buses has the potential for improving the environment and greenhouse gas production situation. However, the acquisition cost and the operating costs of the electric vehicles generate a certain cost structure that is different compared to the diesel vehicles. The amount of state aid as well as possibility of such aid for purchasing electric bus still remains uncertain. The aim of this paper is to highlight the possibility of using life cycle cost analysis to quantify the support for the acquisition of electric buses against diesel buses with respect to the different structure of costs and the time value of money. This difference was set at the level Difference set to $22 \%$, which is a required level for the co-financing from the government, self-governance or EU structural funds. In monetary terms, that means the amount of $132000 €$ for an electric bus.

\author{
KEY WORDS \\ LCC calculation \\ bus transport \\ electric bus \\ environment protection
}

\section{INTRODUCTION}

The goal of logistics is complex satisfaction of specific customers' needs. The transport sector has its irreplaceable part in the logistics chain [1]. Transportation is the essential factor that has a direct impact on economic development [2], [3]. Global demand for transportation services is constantly growing. However, this growth could not be resolved only by building new infrastructure but mainly by internal reorganization and finding innovative potential. Importance must be increased in environmental protection, in particular. Environment and its protection are a regular issue in road transport.

Within the European Union the road transport is the second largest producer of carbon dioxide (CO2), one of the greenhouse gases responsible for climate change. Simpkin et al. [4] states that while some improvements in efficiency of road vehicles have been achieved, the continued growth both in traffic and congestion mean that $\mathrm{CO} 2$ emmisions from road transport have grown overall. At the same time the rising fuel prices and supply instability also put pressure on increased efficiency. The European commision has a declared strategy to reduce overall emissions in particular of $\mathrm{CO} 2$. Reducing the $\mathrm{CO} 2$ generated by road transport is a key aspect of the strategy to reduce the production of greenhouse gases

Many national and trans-national government initiatives are trying to find a solution to this concern. Initiatives Green Growth and Green Economy are considering to promote a sell of ecofriendly transport. The remaining question is the estimated amount of government subsidy for electric automobiles or cofinancing the purchase of electro buses. Effective management tool to help determine the estimation of an investment support for such alternative is Life Cycle Costing (LCC). Life Cycle Cost calculation, also called the process of economic analysis, is a result of managers' effort to minimize costs in the decision making process of technical and economic side of future transformation process [5]. The LCC management tool supports managers in decision making by allocating costs throughout the product life cycle. A significant aspect of LCC is operating with the inflation rate, time value of money and changes in purchase price forecast [6], [7].

\section{THEORETICAL BACKGROUND}

According to the European Environment Agency [8] road transport is the second largest producer of greenhouse gases within the European Union. Electric vehicles (EV) are increasingly being seen as a form of sustainable personal transport in the future [9]. This idea has been reinforced through government policies across the world and aims to reduce greenhouse gas emissions and improve energy security. For example, the European Union aimed to substitute $10 \%$ of 
the conventional fuels used in the road transport sector prior to 2020 [10]. If all the potential benefits of EVs can be realised upon widespread utilization, greenhouse gas emissions, ambient air pollution and foreign oil dependency can all be significantly reduced. Hybrid Electric Vehicles and Full Electric Vehicles offer great $\mathrm{CO} 2$ savings but their market penetration is slow, therefore conventional vehicles will play a significant role in the foreseeable future. Problem that seems to appear is the high rate of acquisition costs in comparison to diesel vehicles. The comparison of the cost structure can be quantified by the methodical approach of LCC calculation. The first International standard for property life - cycle costing BS ISO 15686-5:2008 defines LCC as the methodology for the systematic economic evaluation of life cycle cost over the analysis period, as defined in the agreed scope [7]. Life cycle cost in turn, is defined as the cost of an asset or its parts throughout its life cycle, while fulfilling the performance requirements.

As stated by Popesko and Papadaki [11] LCC calculation allows to strategically manage the costs throughout life cycle of a product or a service. In agreement with Petřík [12] the main purpose of LCC calculation is to optimize all costs throughout the economic life cycle of an asset or investment project without any loss of overall efficiency. According to Šoljakova, [13] the LCC calculation offers an expanded perspective to product costs. LCC operates with research and development costs, pre-production stage costs and post-production stage costs. Petřík [12] stated that Life Cycle Cost calculation operates with costs which are not usually implemented to ordinary operational costing or plan costing. These costs include the purchase or alternatively the establishment of an asset, operating costs and costs related to product withdrawal from the market and its followed liquidation. One of the deciding factors for the achievement of a successful outcome of the LCC calculation method is the correct estimation of overall costs and other factors. Factors such as the length of product life cycle,estimated sales volume during product life cycle and expected product price development.

This information takes into account the aforementioned costs and other decision factors and so it is a base for the utilization of the Life Cycle Cost calculation. This technique allows to quantify the comparable costs of decision alternatives. Costs are allocated in certain time period taking into account all the relevant economic factors. Factors are analysed in terms of the initial costs of acquisition, the future operating and the disposal costs. Liapis and Kantianis [7] declared that the LCC approach identifies all future costs and benefits and reduces them to their present value by the use of discounting techniques through which the economic worth of project options can be assessed. To achieve these objectives the following elements of LCC have been identified: initial capital cost, life of the asset, the discount rate, operating and maintenance costs, disposal cost, information and feedback, uncertainly and sensitivity analysis.

The success of calculation is influenced not only by the total cost estimation but also by other factors such as the duration of the product life cycle, assumed amount of outputs during its life cycle and expected trend of the product prices. The main function is optimizing the life cycle cost of the asset or the investment project without a total performance reduction. The total interaction between all types of cost and revenue of project under consideration is a presumption of life cycle cost optimization. Human resources are an important factor influencing the accomplished expert estimations [14-16]. Time and the used method of economic assessment are the key parameters of appraisal (calculation of Nett Present Value, utilization of discount rate, inclusion of inflation and interest rate) [17], [18].

The calculation applies to the conditions of industrial manufacturing. Publications [19], [20] deal with this issue. Utilization of LCC calculation is frequent in the construction industry. This is discussed in publications [21], [22]. The calculation is most commonly used in connection with the issue of the Environmentand the Ecology, as is evident in papers [23], [24] and [25]. Occasionally it is possible to find publications dealing with the application of this calculation in rail transport [26], in maritime transport [27] and in road transport [28-31]. The research of Jalunen and Lipman is interesting [32] and states that an extensive lifecycle cost analysesindicates that electric buses are already economically competitive with diesel buses and electric buses which would become cost effective in the near future. They use three main lifecycle cost categories for analyses: capital cost $\left(C_{C A P}\right)$, operating cost $\left(C_{O P}\right)$ and technology replacement cost $\left(C_{R E P}\right)$. Equation (1) describes the annualized lifecycle cost calculation for a bus fleet. $\mathrm{N}_{\text {Bus }}$ is the number of buses in operation and $\mathrm{d}_{\text {rate }}$ is the discount rate:

$$
\text { Total LCC }=N_{B U S} x C_{C A P}+\left(C_{O P}+C_{R E P}\right) x\left(1+d_{\text {rate }}\right)^{-j}
$$

Kara, Li a Sadvija [9] at their work use the Life Cycle Cost Analysis of Electrical Vehicles in Australia. For a comparison between typical and electricity vehicles, they use the following equation (2) according to Dhillon, where $C_{A}$ is the acquisition cost, $O C_{i}$ the operating cost for a given year, $S M C_{i}$ the scheduled maintenance cost, $\mathrm{UMC}_{\mathrm{i}}$ the unscheduled maitenance cost and DC the Disposal cost of car:

$$
\text { Total }=\text { Acquisition Cost }+O C i+S M C i+U M C i+D C
$$

In our research we present the deterministic approach [6]. The equation for calculation of the current value of the total life cycle cost was determined as follows (3):

$$
L C C=C_{A}+\sum_{t=1}^{L C} C_{t} \times \frac{(1+r)^{n}-1}{(1+r)^{n} \times r} \pm\left(\frac{1}{(1+r)^{n}} \times N B V\right)
$$

where:

LCC - Current Value of Total Life Cycle Cost

$C A-$ Acquisition Cost

$r$ - Discount Rate (time value of money)

LC - Life Cycle

$C T$ - sum of relevant Life Cycle Cost of property after deducting the positive cash flow

NBV -Net Book Value

Currently, the issue of electro mobility is often discussed. The acquisition of eco-friendly cars or electric buses has the potential for improving the environment and greenhouse gas production situation. However, the acquisition cost and the operating costs of the electric vehicles generate a certain cost structure that is different compared to the diesel vehicles. The amount of state support as well as the possibility of such aid for purchasing electric buses still remains uncertain. The aim of this paper is to highlight the possibility of using life cycle cost analysis to quantify the support for the acquisition of electric buses against diesel buses with respect to the different structure of costs and the time value of money. 
Battery electric city buses have developed rapidly in recent years [33]. There are several different manufacturers in the market and also the big bus manufacturers have shown interest in developing them [34]. There are several different operating methods for electric buses due to the different options in charging methods. The battery can be charged overnight at the depot, it can be charged during operation at the end stations, or during the route in the dedicated bus stops. According to Scrosati and Garche [35] recent technological development with lithium-based batteries and associated "battery management systems" have made them the best choice as the energy storage for electric buses.

\section{METHODOLOGY}

The objective of our case study is to decide between electric bus and standard diesel engine bus (figure 1). Alternative solutions for city transport are reviewed in Bratislava, capital of Slovakia. The required annual duty has been set to $72072 \mathrm{~km}$ on the bus line Trnavské Mýto - Vajnory (distance 11 km).

The estimated purchase costs are based on the values presented on producers web sites [36], [37]. Lifetime of an electric bus was set to 10 years. The purchase cost is set to $577,777 €$, including battery (lifetime $700000 \mathrm{~km}$ ) and charging station [38]. Purchase cost of the diesel engine bus with similar passenger capacity is set to $234,000 €$. The cost of fuel and electricity corresponds to average prices in 2017 in Slovakia. Based on the data from the Statistical Office of the Slovak Republic up to February 8, 2018, the expected diesel and electricity price growth were set as an average to year-to-year price change for 2009 to 2017 [39-41].

Operating costs of the selected cost items (fuel cost, electricity cost, maintenance costs, oil change cost, tire change cost) were set by the following equations:

- Fuel cost (diesel) was calculated on the basis of average consumption (AC) from vehicle technical documentation, estimated distance travel $(\Sigma \mathrm{km})$ and expected diesel price for the current period (DP/I)

$$
\text { fuel cost }=\frac{\left(\frac{A C}{100} \mathrm{~km} \times \sum \mathrm{km}\right)}{100} \times D P
$$

Electricity cost was calculated on the basis of average battery consumption (AC) from vehicle technical documentation, estimated travel distance $(\Sigma \mathrm{km})$ and expected electricity price change for the current period (EP/I)

$$
\text { electricity cost }=\frac{\left(\frac{A C}{100} \mathrm{~km} \times \sum \mathrm{km}\right)}{100} \times E P
$$

Maintenance costs - oil change (diesel engine bus alternative only) was calculated on the basis of oil change interval (I - 25 $000 \mathrm{~km}$ ), oil tank volume (Ov) and motor oil price (MOP - €/I).

$$
\text { Maintenance engine oil costs }=\frac{(\mathrm{O} v \times \mathrm{MOP})}{1}
$$

Maintenance costs - tire change cost depends on tire price (TP), tire count (c), tire change payments (TCP), tire lifespan $(\mathrm{TL} / \mathrm{km})$ and the mileage of a tire $(\Sigma \mathrm{km})$. The replacement interval was set twice a year.

$$
\text { cost of tires }=\frac{(T P \times c)+T C P}{T L / k m} \times \sum k m
$$

Determination of operating costs also required the calculation of other costs. Other costs were defined as a planned repair and maintenance (washing, disinfection, standard repairs), vehicle emissions control and technical control (2-year intervals) and regular vehicle service control at a mileage of $10000 \mathrm{~km}$.

For applying the LCC calculation, it is required to have data about the discount rate, price rate and life cycle. Petrík [12] states that it is necessary to modify the discount rate if the cash flows are displayed in the stable price and the inflation rate is low and stable. Authors of the publication [42] also modify the discount rate by using the inflation rate, and therefore the discount rate would be quantified by the following equation (8). We used $2.5 \%$ rate of return on the financial market and price inflation rate of fuel and electricity.

$$
\text { discount rate }(r)=\frac{\emptyset \text { interest rate } \times 100}{\emptyset \text { inflation rate } \times 100}
$$

Foltíniová et al. [43], see the advantage of LCC calculation mainly in including complex costs into the decision making process through discount methods. When calculating total life cycle costs, we also used the value of the RBF (Rentenbarwertfaktor) indicator. This indicator reflects the time factor to net present value for annuity (series of payments made at equal intervals) operating costs.

$$
R B F=\frac{(1+r)^{n}-1}{(1+r)^{n} \times r}
$$

$r$ - discount rate

$\mathrm{n}$ - analysed period

Heralová [17], Wagner [44], Seif and Rabbani [45] and also Pavlickova and Teplická [46] also states that in addition to costs the major parameters for examination are time and used method for economic valuation. Thus, using of discount rate, including inflation rate and interest rate. For determination of LCC we calculated with the following equation, while the carrying value was disregarded after the expiration of a lifetime.

$$
L C C=\text { acquisition cost }+ \text { operating cost } \times R B F+\left(\text { residual price } \times \frac{1}{(1+r)^{n}}\right)
$$
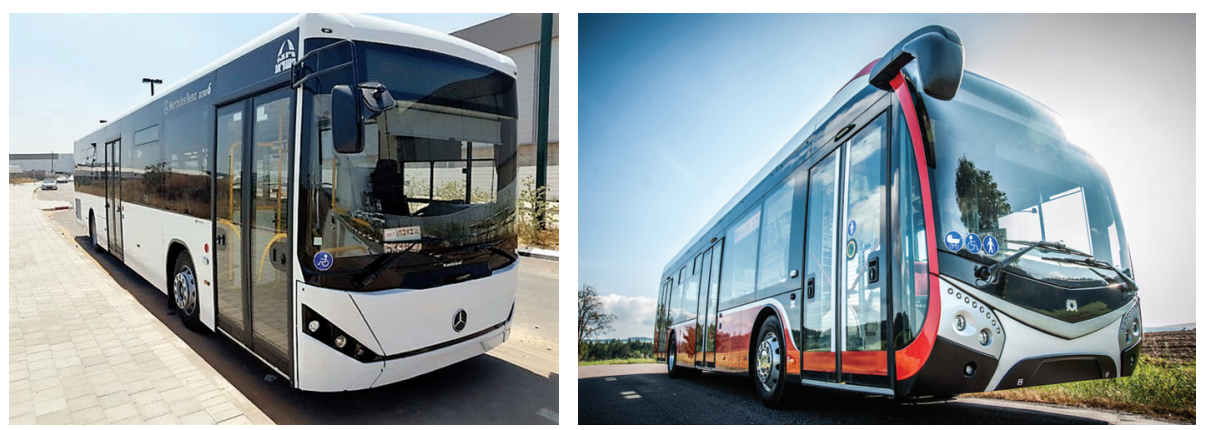

Source: [36], [37]

Figure 1 Diesel Bus MERCEDES - BENZ, Merkavim Pioneer and electric bus SOR-NS-12-electric 


\section{RESULTS AND DISCUSIONS}

Additional life cycle cost calculation parameters are shown in Table 1, below. The fuel and electricity costs correspond to the average prices in 2017 in Slovakia. Diesel costs with VAT were set to $1.169 € /$ liter and electricity costs with VAT were set to 0.08 $€ / \mathrm{kWh}$. Inflation rate of fuel prices and electricity prices were set to $1.20 \%$ with interest rate $2.50 \%$ p.a. Based on previously mentioned indicators it is possible to quantify the discount rate:

$$
\text { discount rate }(r)=\frac{2.5 \times 100}{1.2 \times 100}=2.083 \%
$$

and the RBF factor. In our case the RBF factor, determined by relation 9 , has the following value:

$$
R B F=\frac{(1+0.0283)^{10}-1}{(1+0.0283)^{10} \times 0.0283}=8.94
$$

With an estimated 72,072 km / year and average diesel / electric power consumption, the operating cost of consumption is based on relationships 4 and 5 at 26,661.69€/year for the diesel bus and 7,322.52 $€ /$ year for the electric bus. Maintenance costs - tire change cost and oil change (determined by relationships 6 and 7) as well as other repairs, servicing, technical and emission controls are presented in Table 1.

For determination of the LCC the relation 10 was used, based on which it is possible to declare that Life Cycle Costs are: - for electric bus: $L C C=577,777+(12,672.02 \times 8,94)+0$ $\doteq 691,073.85 €$

- for diesel bus: $L C C=234,000+(36,380.09 \times 8,94)+0$ $\doteq 559,256.51 €$

LCC analysis resulted in the statement that the total life cycle costs are higher at the alternative of electric bus acquisition, as illustrated in Figure 2. The difference of life cycle costs between analysed alternatives is the sum of $132,000 €$, for a 10 -year lifetime.

Figure 3 shows the cost structure development in individual years of life cycle during the use of electric and diesel buses. However, this assumption is based on the constancy of reviewed parameters (fuel price development, electricity price, interest rate) for life cycle longer than 10 years. According to the presented data the payback has been set to 17.5 years. This data significantly exceeds the means of transport and their life cycle as well as their battery, but the potential of positive impact to

\begin{tabular}{|c|c|c|}
\hline & $\begin{array}{l}\text { Diesel bus (city bus) MER- } \\
\text { CEDES - BENZ, Merkavim } \\
\text { Pioneer }\end{array}$ & $\begin{array}{l}\text { Electric bus } \\
\text { SOR-NS-12-electric }\end{array}$ \\
\hline Acquisition cost & $234,000 €$ & $577,777 €$ \\
\hline Lifetime & 10 years & 10 years \\
\hline Discount rate (average interest) & $2.50 \%$ p.a. & $2.50 \%$ p.a. \\
\hline Diesel fuel cost with VAT & $1.169 € /$ liter & - \\
\hline Electricity cost with VAT & - & $0.08 € / \mathrm{kWh}$ \\
\hline Diesel and electricity price increase (last 10 years) & $1.20 \%$ & $1.20 \%$ \\
\hline Distance (per year) & $72,072 \mathrm{~km} /$ year & $72,072 \mathrm{~km} /$ year \\
\hline Average fuel/electricity consumption & 32 liter/100km & $1.27 \mathrm{kWh} / \mathrm{km}$ \\
\hline Fuel / electricity cost of consumption & $26,960.69 € /$ year & $7,322.52 € /$ year \\
\hline Maintenance costs - tire change cost & $3,300 € /$ year & $3,300 € /$ year \\
\hline Maintenance costs - oil change & $900 € /$ year & - \\
\hline $\begin{array}{l}\text { Other cost } \\
\text { - Repairs (brake maintenance, cleaning parts of bus) } \\
\text { - Technical Inspection } \\
\text { - Emission control } \\
\text { - Service control }\end{array}$ & $\begin{array}{r}1,600 € / \text { year } \\
50 € / \text { year } \\
70 € / \text { year } \\
3,500 € / \text { year }\end{array}$ & $\begin{array}{r}600 € / \text { year } \\
50 € / \text { year } \\
- \\
1,400 € / \text { year }\end{array}$ \\
\hline Residual value (\% from the acquisition costs) & $0.00 \%$ & $0.00 \%$ \\
\hline
\end{tabular}

Table 1 The structure of cost for LCC calculation

Source: authors

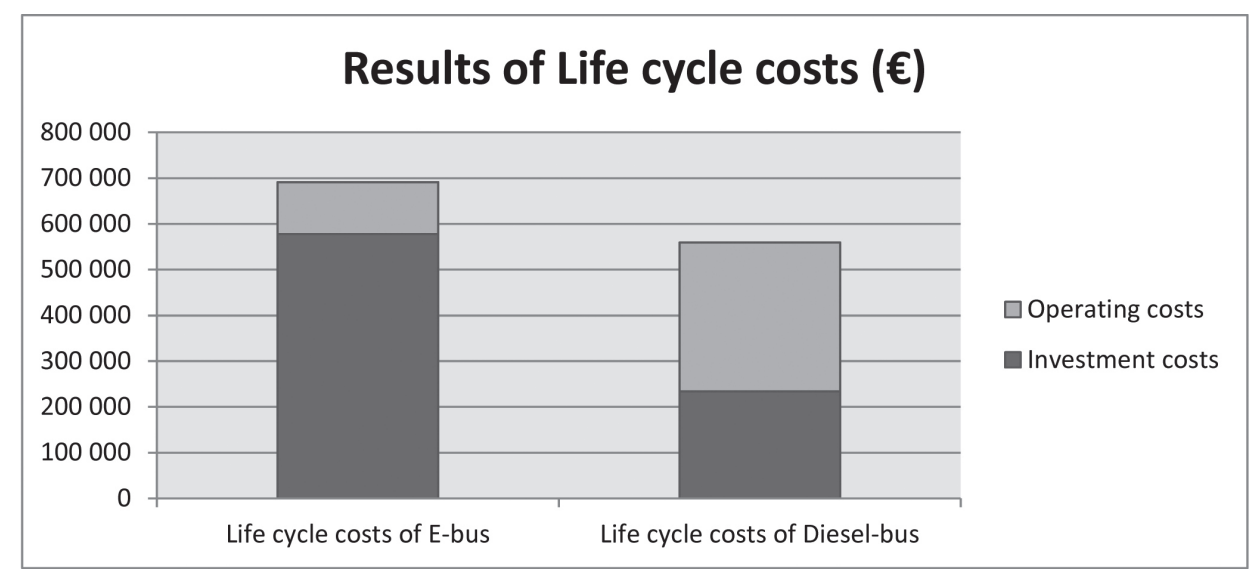

Source: authors

Figure 2 Results of Life Cycle Cost Analysis 


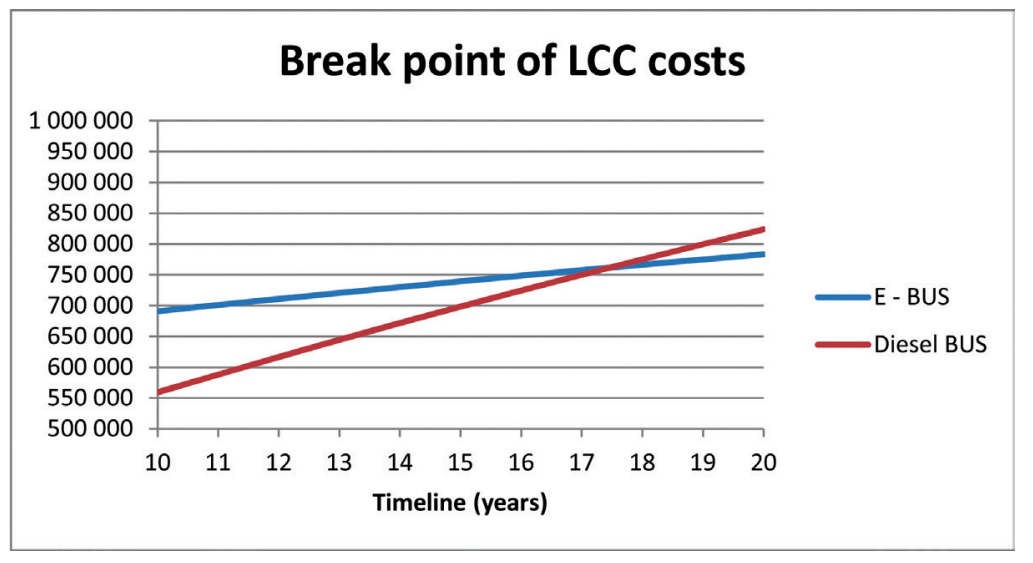

Source: authors

Figure 3 Break point of LCC costs

the environment is in this case insignificant. The results of this impact are introduced in studies [32], [47] and [48]. We did not regard this impact in our article.

\section{CONCLUSION}

Several aspects are needed to evaluate the operation of electric buses. Unlike the conventional diesel buses and hybrid buses, the electric buses necessitate the restricted charging infrastructure and the charging configuration must suit the selected operating route and plan. The main goal of this article was to apply the life cycle analysis to compare life cycle costs of conventional city transport represented by diesel buses with options for alternative transport-electric buses. The comparison is quantified in nominal representation as well as in relative representation to the acquisition cost. From the outcome of life cycle analysis of selected means of transport, we can state that overall costs for an electric bus at 10-year lifetime are 691,073 $€$ and 559,256 $€$ for the diesel version. City electric buses and high-power charging systems have developed rapidly in recent years. Electric buses using batteries are energy efficient and also emissions-free, but due to expensive technology the life cycle costs are in comparison to diesel buses considerably higher. For the assumed parameters this difference between life cycle costs is $131817 €$ which represents $22.81 \%$ of the electric bus acquisition price. This is the required amount of financial support for carrier's competitiveness. A form of support for ecofriendly city transport may consist of self-governance standards, government standards as well as European standards for funding because of the presented policy for sustainable development. From the environmental protection point of view, this could be the solution for future means of transport.

\section{Acknowledgement}

This article is a part of the work on the project of VEGA 013TU 1/0320/17 Economic and Social Context of European 20/20/20 Targets from the Viewpoint of Economy Low-energy Houses.

\section{REFERENCES}

[1] Kampf, R., Cejka, J., Telecky, M. Applicability of the dea method on the transport undertakings in selected regions. Communications - Scientific Letters of the University of Zilina, 2016, Vol. 18, Issue 2, pp. 129-132. ISSN 1335-4205.

[2] Potkány, M., Hitka, M., Krajčírová, L. Life cycle cost calculation at the transport company in the supply of production of wooden houses - Case study. EDP SciencesMATEC Web Of conferences, Logi 2017, Vol. 134. https://doi. org/10.1051/matecconf/201713400049
[3] Hitka, M., Vetráková, M., Balážová, Ž., Danihelová, Z. Corporate Culture as a Tool for Competitiveness Improvement. Procedia Economics and Finance, 2015, Vol. 34, 27-34. https://doi.org/10.1016/S2212-5671(15)01597-X

[4] Simpkin, R. et al. Energy Efficient Vehicles for Road Transport. Procedia Social and Behavioral Sciences, 2012, Vol. 48, pp. 3613-3621. https://doi. org/10.1016/j.sbspro.2012.06.1324

[5] Parobek, J., Paluš, H., Šupín, M., Dvorácek, J. Comparison of green growth indicators in the EU. Proceedings of Scientific Papers - More Wood, Better Management, Increasing Effectiveness: Starting Points and Perspective, 2017, pp. 38-43. ISBN 978-802132761-0.

[6] Kampf, R., Potkány, M., Krajčírová, L., Marcineková, K. Life cycle cost calculation and its importance in vehicle acquisition process for truck transport. Nase More, 2016, Vol. 63, Issue 3, pp 129-133. https://doi.org/10.17818/NM/2016/ SI10

[7] Liapis, K. J., Kantianis, D. D. Depreciation Methods and Life-Cycle Costing (LCC) Methodologhy. Procedia Economic and Finance. Vol. 19, 2015, pp 314324. https://doi.org/10.1016/S2212-5671(15)00032-5

[8] European Environment Agency. Greenhouse gas emissions from transport. [cit. 2018. 02.12.]. Available online: https://www.eea.europa.eu/data-andmaps/indicators/transport-emissions-of-greenhouse-gases/transportemissions-of-greenhouse-gases-10.

[9] Kara, S., Li, W., Sadjiva, N. Life Cycle Cost Analysis of Electrical Vehicles in Australia. Procedia CIRP - Conference on Life Cycle Engineering, 2017, Vol. 61, pp. 767-772. https://doi.org/10.1016/j.procir.2016.11.179

[10] Bakker D. Battery electric vehicles: Performance, CO2 emissions, lifecycle costs and advanced battery technology development. University of Utrecht. Master thesis. 2010.

[11] Popesko, B., Papadaki, Š. 2016. Moderní metody řízení nákladů. Jak dosáhnout efektivního vynakládání nákladů a jejich snižení. Prague: Grada Publishing, a. s., 2016, 264 p. ISBN 978-80-247-5773-5.

[12] Petřík, T. Procesní a hodnotové řízení firem v organizací - nákladová technika a komplexní manažerská metoda: $A B C / A B M$ (Activity Based Costing/Activity Based Management). Prague: Linde, 2007, 911 p. ISBN 978-80-7201-648-8.

[13] Šoljaková, L. Strategicky zaměřené manažerské účetnictví. Praha: Management Press, 2009, 206 p. ISBN 978-80-7261-199-7.

[14] Stacho, Z., Urbancová, H. Stachová K. Organisational arrangement of human resources management in organisations operating in Slovakia and Czech Republic. Acta Universitatis Agriculturae et Silviculturae Mendelianae Brunensis, 2013, Vol. 61, Issue 7, pp.2787-2799. ISSN 1211-8516.

[15] Urbancová, H., Stachová K. Importance of organisational culture of knowledge continuity ensuring in organisations (in Czech). Scientific Papers of the University of Pardubice, 2013, Vol. 27, Issue 2, pp. 140-149. ISSN 1211 $555 \mathrm{X}$.

[16] Lorincová, S., Hitka, M., Čambál, M., Szabó, P., Javorčíková, J. 2016 Motivational factors influencing senior managers in the forestry and woodprocessing sector in Slovakia. BioResources, 2016, Vol. 11, No.4, pp. https:// doi.org/10.15376/biores.11.4.10339-10348

[17] Heralová, R.S. Life Cycle Cost optimization within decision making on alternative designs of public buildings. Procedia Engineering, 2014, Vol. 85, pp 454-463. ISSN 1877-7058.

[18] Hajduová, Z., Andrejkovič, M., Mura, L. Utilizing experiments designed results during error identification and improvement of business processes. Acta Polytechnica Hungarica, Vol. 11, No. 2, 2014, pp. 149-166. ISSN 1785-8860.

[19] Kunttu, S., M. Reunanen, J. Raukola, K. Frankenhaeuser, K. Frankenhaeuser. Executing sustainable business in practice a case study on how to support sustainable investment decisions. Lecture Notes in Mechanical Engineering, 2015, Vol. 19, pp. 1095-1107. ISSN 2195-4356.

[20] Seif, J., Rabbani, M. Component based life cycle costing in replacement decisions. Journal of Quality in Maintenance Engineering, 2014, Vol. 20, Issue 4, pp. 436-452. ISSN 1355-2511. 
[21] Brown, N.W.O., T. Malmqvist, W. Bai, M. Molinari. Sustainability assessment of renovation packages for increased energy efficiency for multi-family buildings in Sweden. Building and Environment, 2013, Vol. 61, pp. 140-148. ISSN 0360-1323.

[22] Stephan, A., L. Stephan. Life cycle energy and cost analysis of embodied operational and user-transport energy reduction measures for residential buildings. Applied Energy, 2016, Vol. 161, Issue 1, pp. 445-464. ISSN 03062619.

[23] Rigamonti, L., Sterpi, I., Grosso, M. Integrated municipal waste management systems: An indicator to assess their environmental and economic sustainability. Ecological Indicators, 2016, Vol. 60. pp. 1-7. ISSN 1470-160X

[24] Schmidt Rivera, X., C., A. Azapagic. Life cycle costs and environmental impacts of production and consumption of ready and home-made meals. Journal of Cleaner Production, 2016, Vol. 112, Issue 1, pp. 214-228. ISSN 0959-6526.

[25] Qiao, Y., A. Dawson, G. Flintsch. Evaluating the effects of climate change on road maintenance intervention strategies and Life-Cycle Costs. Transportation Research Part D: Transport and Environment, 2015, Vol. 41, pp 492-503. ISSN 1361-9209.

[26] Babel, M., M. Szkoda. Diesel locomotive efficiency and reliability improvement as a result of power unit load control system modernisation. Eksploatacja i Niezawodnosc. 2016, Vol. 18, Issue 1, pp. 38-49. ISSN 1507-2711.

[27] Luttenberger, A., R. L. Luttenberger. Environmental Life Cycle Costing in Maritime Transport. Proceedings 16th IAUMU Annual General Assembly Opatija, Croatia, 2015, Available on: https://www.researchgate.net/ publication/283302664_Environmental_life-cycle_costing_in_maritime_ transport.

[28] Simkova, l., Konecny, V. Key performance indicators in logistics and road transport. Logi - Scientific Journal on Transport and Logistics, 2014, Vol. 5, No. 2, pp. 87-96, ISSN 1804-3216.

[29] Zhang, J., Wnag, J.J. Liu, K. Highway life - cycle cost analysis with environment impact considered. Journal of Chang'an University (Natural Science Edition), 2014, Vol. 34, Issue 3, pp. 128-132. ISSN 1671-8879.

[30] Włudyka, S., Orłowski, K. Ecological aspects of logistics in various kinds of transport. Scientific Journals of the Maritime University of Szczecin, 2009, Vol. 16, No. 88, pp. 70-76. ISSN 1733-8670.

[31] Droździel, P., Komsta, H., Krzywonos, L. An analysis of costs of vehicle repairs in a transportation company. Part I. Problemy Transportu/Transport Problems, 2012, Vol. 7, Issue 3, pp. 67-75. ISSN 1896-0596.

[32] Lajunen, A., Lipman, T. Lifecycle cost assessment and carbon dioxide emissions of diesel, natural gas, hybrid electric, fuel cell hybrid and electric transit buses. Energy, Vol 106, 2016, pp.329-342. https://doi.org/10.1016/j. energy.2016.03.075

[33] Choi, U.D., Jeong, H.K., Jeong, S.K. Commercial operation of ultra low floor electric bus for Seoul city route. IEEE vehicle power and propulsion conference, 2012. [cit. 2018. 02.12.]. Available online: http://ieeexplore.ieee. org/document/6422619/?reload=true.
[34] Göhlich, D., Kunith, A., Ly, T. Technology assessment of an electric urban bus system for Berlin. Urban Transport 2014, [cit. 2018. 02.12.]. Available online: https://www.researchgate.net/publication/263224970_Technology assessment_of_an_electric_urban_bus_system_for_Berlin.

[35] Scrosati, B., Garche, J. Lithium batteries, status, prospects and future. Journal of Power Sources, 2010, Vol. 195, Issue 9, pp 2419-2430. https://doi. org/10.1016/j.jpowsour.2009.11.048

[36] Mercedes-Benz-Merkavim-Pioneer. [cit. 2018. 02.12.]. Available online: https://autoline.sk/-/predaj/mestske-autobusy/MERCEDES-BENZ-MerkavimPioneer--7092910245791275800.

[37] Electric bus SOR-NS-12-electric. [cit. 2018. 02.12.]. Available online: https:// www.sor.cz/en/ens/.

[38] Lajunen, A. Lifecycle costs and charging requirements of electric buses with different charging methods. Journal of Cleaner Production, 2018, Vol 172, pp. 56-67. https://doi.org/10.1016/j.jclepro.2017.10.066

[39] Statistical office of the Slovak Republic. [cit. 2018. 02.12.]. Available online: https://slovak.statistics.sk/wps/portal/ext/home/lut/p/z1/hY5NC4JAEIZ SwevzoiaW7c1wg9E0gptL6GwrZa6opZ_P6kuQR9ze-d9nmGAQQqsyW6lyIZSN k15QObHyPLI7atUSRhvEZvRzdO7BsaGiYk_wA21fhIKE4-eyArh7qGFSCSwDHRo4-XkS6jIR_AT9uhK6sOWx5Az4wUcn8-Thtcp0IYB0_8Y536rWb1sUwtP 1SQQXHcVSFIKLian9R8JNRyH6A9A2Etk7xbDgJ6ensDhRe4u4!/dz/d5/ L2dBISEvZOFBIS9nQSEh/.

[40] National Bank of Slovakia. [cit. 2018. 02.12.]. Available online: https://www. $\mathrm{nbs.sk/sk/menova-politika/menova-politika-ecb-od-roku-2009.}$

[41] AutoSME. [cit. 2018. 02.12]. Available online: http://auto.sme.sk/ natankuj/?submenu=priemerne_ceny

[42] Baum, H.G., Coenenberg, A.G. Günther, E. Betriebliche Umweltökonomie in Fällen. Band I: Anwendung betriebswirtschaftlicher Instrumente. [online]. München, 1999, ISBN 978-3-486-24675-5.

[43] Foltínová, A. a kol. Nákladový controlling. Bratislava: Sprint, 2007, 450 s. ISBN 978-80-89085-70-5

[44] Wagner, J. Měření výkonnosti. Jak měřit, vyhodnocovat a využívat informace o podnikové výkonnosti. Praha: Grada Publishing, a. s., 2009. 256 s. ISBN 97880-247-2924-4.

[45] Seif, J., Rabbani, M. 2014. Component based life cycle costing in replacement decisions. Journal of Quality in Maintenance Engineering. Vol. 20, Issue 4 2014, s. 436-452. ISSN 1355-2511

[46] Pavlíčková, M., K. Teplická. Application of operational analysis methods in alternative energy sources. Acta Montanistica Slovaca, 2014, Vol. 19, Issue 2 , pp. 59-64. ISSN 1335-1788.

[47] Zhang, S., Wu, Y., Liu, H., Huang, R., Yang, L. et al. Real-world fuel consumption and $\mathrm{CO} 2$ emissions of urban public buses in Beijing. Applied Energy, 2014 Vol. 113, pp. 1645-1655. https://doi.org/10.1016/j.apenergy.2013.09.017

[48] Chan, S., Miranda-Moreno, L.F., Alam A., Hatzopoulou, M. Assesing the impact of bus technology on greenhouse gas emissions along a major corridor: a lifecycle analysis. Transportation Research Part D: Transport and Environment, 2013, Vol. 20, pp 7-11. https://doi.org/10.1016/j.trd.2013.01.004 